\title{
Helminths and Pentastomida of two synanthropic gecko lizards, Hemidactylus mabouia and Phyllopezus pollicaris, in an urban area in Northeastern Brazil
}

\author{
Sousa, JGG. ${ }^{a}$, Brito, SV. ${ }^{b}$ Ávila, RW. ${ }^{c}$, Teles, DA. ${ }^{a}$, Araujo-Filho, JA. ${ }^{c}$, \\ Teixeira, AAM. ${ }^{a}$, Anjos, LA. ${ }^{d}$ and Almeida, WO. ${ }^{* *}$
}

\begin{abstract}
aPrograma de Pós-Graduação em Bioprospecção Molecular, Departamento de Química Biológica, Universidade Regional do Cariri - URCA, Rua Cel. Antônio Luiz, 1161, Campus do Pimenta, CEP 63105-000, Crato, CE, Brazil

bPrograma de Pós-Graduação em Ciências Biológicas (Zoologia), Departamento de Sistemática e Ecologia - DSE,

Centro de Ciências Exatas e da Natureza - CCEN, Universidade Federal da Paraíba - UFPB,

Cidade Universitária, Campus I, CEP 58059-900, João Pessoa, PB, Brazil

'Departamento de Ciências Biológicas, Universidade Regional do Cariri - URCA, Rua Cel. Antônio Luiz,

1161, Campus do Pimenta, CEP 63105-000, Crato, CE, Brazil

${ }^{\mathrm{d}}$ Departamento de Biologia e Zootecnia, Faculdade de Engenharia de Ilha Solteira, Universidade Estadual Paulista - UNESP, Passeio Monção, 226, CEP 15385000, Ilha Solteira, SP, Brazil

'Departamento de Química Biológica, Universidade Regional do Cariri - URCA, Rua Cel. Antônio Luiz, 1161, Campus do Pimenta, CEP 63105-000, Crato, CE, Brazil

*e-mail: waltecio@gmail.com
\end{abstract}

Received: March 11, 2013 - Accepted: July 8, 2013 - Distributed: December 31, 2014

\begin{abstract}
Helminths and pentastomids were examined in exotic Hemidactylus mabouia and native Phyllopezus pollicaris lizards, living synanthropically in an urban area in the municipality of Crato, Ceará state, northeastern Brazil. A total of 194 lizards were collected, being 76 specimens of $H$. mabouia e 118 specimens of P. pollicaris. Six parasite species were found infecting H. mabouia: the cestode Oochoristica sp., the nematodes Parapharyngodon sceleratus, Physaloptera retusa, Physalopteroides venancioi, and Spauligodon oxkutzcabiensis and the pentastomid Raillietiella mottae; while four parasite species were found associated with P. pollicaris: Oochoristica sp., P. sceleratus, P. retusa, and S. oxkutzcabiensis. Three new host records were reported: $P$. retusa infecting H. mabouia and P. retusa and Oochoristica sp. infecting P. pollicaris. About $75 \%$ of the parasites species found were shared by both lizards. Moreover, H. mabouia showed greater diversity than $P$. pollicaris (6 versus 4 species), while $P$. pollicaris had higher intensity of infection than H. mabouia (1536 versus 121 specimens).
\end{abstract}

Keywords: parasites, lizards, Pentastomida, Nematoda, Cestoda.

\section{Helmintos e pentastomídeos de dois lagartos sinantrópicos, Hemidactylus mabouia e Phyllopezus pollicaris, de uma area urbana da região Nordeste do Brasil}

\section{Resumo}

Helmintos e pentastomídeos foram analisados em lagartos exóticos Hemidactylus mabouia e nativos Phyllopezus pollicaris, vivendo sinantropicamente em uma área urbana da cidade de Crato, Estado do Ceará, Nordeste do Brasil. Foram coletados 194 lagartos, sendo 76 espécimes de H. mabouia e 118 de P. pollicaris. Seis espécies de parasitas foram encontradas infectando H. mabouia: Oochoristica sp., Parapharyngodon sceleratus, Physaloptera retusa, Physalopteroides venancioi, Spauligodon oxkutzcabiensis e Raillietiella mottae; enquanto em P. pollicaris foram encontradas quatro espécies: Oochoristica sp., P. sceleratus, P. retusa, and S. oxkutzcabiensis. Três novos registros de hospedeiros são reportados: P. retusa em H. mabouia e Oochoristica sp. e P. retusa infectando P. pollicaris. Cerca de $75 \%$ dos parasitas encontrados foram compartilhados pelas espécies de lagartos. Ainda, H. mabouia apresentou maior diversidade de parasitas do que $P$. pollicaris (6 espécies versus 4), enquanto $P$. pollicaris possui maior intensidade de infeç̧ão media do que H. mabouia (1.536 versus 121$)$.

Palavras-chave: parasitas, lagartos, Pentastomida, Nematoda, Cestoda. 


\section{Introduction}

The lizard Hemidactylus mabouia (Moreau de Jonnès, 1818) is an African species, successfully established and widely distributed throughout South, Central (except Jamaica) and North America (Rocha et al., 2011). In the latter, H. mabouia rapidly colonized large areas and dislocated two other exotic congeners: Hemidactylus garnotti Duméril and Bibron, 1836 and Hemidactylus turcicus (Linnaeus, 1758) (Kluge, 1969; Vanzolini, 1978; Lawson et al., 1991; Howard et al., 2001; Anjos and Rocha, 2008). Hemidactylus mabouia is commonly encountered in or near anthropic environments in Brazil (Vanzolini, 1978; Rocha et al., 2011) as well as in natural environments in Amazon, Atlantic rainforest, Cerrado (Brazilian savanna), Caatinga (semi-arid) and Restinga (sandy coastal) biomes and some coastal islands (Vanzolini, 1978; Vanzolini et al., 1980; Araujo, 1991; Vitt, 1995; Rocha et al., 2000; Rocha et al., 2002). Invasion by H. mabouia are mainly reported in the states of Rio de Janeiro, São Paulo, Bahia, Ceará and some continental islands (Rocha et al., 2011). This nocturnal lizard is a generalist sit-and-wait predator that feeds mainly on arthropods such as spiders, insect larvae, and termites (Vitt, 1995; Rocha and Anjos, 2007).

Phyllopezus pollicaris (Spix, 1825) is a nocturnal lizard (Vanzolini et al., 1980) native to South America, distributed from northeastern Brazil to Paraguay. Is inhabitant of rock outcrops, but also commonly found in human habitations (Vanzolini et al., 1980; Vitt, 1995). This lizard is also a typical sit-and-wait opportunist that feeds on arthropods (principally crickets, ants, termites, spiders, insect larvae, and beetles) (Vitt, 1995; Recorder et al., 2012).

The macro-endoparasitic faunas associated with H. mabouia in Old and New Worlds have been extensively studied and include species of Acantocephala, Cestoda, Nematoda, Pentastomida, and Trematoda (Rodrigues, 1970, 1986, 1994; Simonsen and Sarda, 1985; Moravec et al., 1987; Bursey et al., 1997; Rodrigues et al., 1990; Anjos et al., 2005, 2007). On the other hand, information about the parasite fauna associated with $P$. pollicaris, is rather scarce, and only three species of Nematoda and one Pentastomida are currently known (Almeida et al., 2008; Ávila and Silva, 2010; Ávila et al., 2012).

The present study: (i) describes and identifies the macro endoparasitic fauna infecting the exotic lizard species $H$. mabouia and the native $P$. pollicaris that inhabit human habitations synanthropically, and (ii) compared the infection rates of host species.

\section{Material and Methods}

Lizard specimens were collected between March and November/2011 in human habitations in the municipality of Crato $\left(07^{\circ} 14^{\prime}\right.$ S and $\left.39^{\circ} 24^{\prime} \mathrm{W}\right)$, Ceará State, semi-arid region of northeastern Brazil. The regional climate is predominantly tropical, hot, and semi-arid (temperatures varying from $20^{\circ} \mathrm{C}$ to $34^{\circ} \mathrm{C}$, and average annual varying from $24{ }^{\circ} \mathrm{C}$ to $26^{\circ} \mathrm{C}$ ) (IPECE, 2011).

Lizards were collected manually, euthanized with lethal doses of lidocaine $2 \%$, fixed in $10 \%$ formaldehyde, and preserved in $70 \%$ ethanol. The snout-vent length (SVL) of each lizard was measured using a digital caliper $( \pm 0.01$ $\mathrm{mm})$. Lizards were weighed by Pesola ${ }^{\circledR}$ spring scales (precision: 0.1g). Host specimens were deposited in the Coleção Herpetológica of the Universidade Regional do Cariri - URCA. The body cavities of the lizards were exposed by making a longitudinal incision from the neck to the cloaca, and their lungs and digestive tracts were removed and examined for endoparasites using a stereomicroscope. For identification, pentastomids were cleared using Hoyer's solution; nematodes were cleared in lactophenol; and the cestodes were stained with Carmim, dehydrated in an increasing alcohol series and cleared in creosote. The cestodes, nematodes and pentastomids were mounted on temporary slides for identification. Voucher parasite specimens were subsequently deposited in the Coleção parasitological at URCA.

Prevalence (lizards infected/total number of lizards examined x 100), mean intensity of infection (number of parasites/number of infected hosts) were calculated according to Bush et al. (1997). Sorensen's similarity index (range $0=$ no similarity, to $1.0=$ identical) were calculated for the communities of parasites infecting $H$. mabouia and P. pollicaris, not considering juvenile parasites.

A Mann Whitney U test was performed to determine differences in the size (SVL) of male and female hosts and check for differences in parasite abundance between the sexes. To check variations in prevalence and intensity of infection between the two species of lizards we used a $\mathrm{Z}$ test and a $\mathrm{T}$ test, respectively.

\section{Results}

A total of 194 lizards were collected: 76 specimens of H. mabouia, including 11 males $(\mathrm{SVL}=56.71 \pm 9.68 \mathrm{~mm})$, 29 females $(\mathrm{SVL}=57 \pm 6.74 \mathrm{~mm})$, and 36 juveniles $(\mathrm{SVL}=31.5 \pm 5.39 \mathrm{~mm})$; and 118 specimens of $P$. pollicaris, including 44 males $(\mathrm{SVL}=66 \pm 10.82 \mathrm{~mm}), 64$ females $(\mathrm{SVL}=66.5 \pm 9.5 \mathrm{~mm})$, and 10 juveniles $(\mathrm{SVL}=31 \pm 3.05 \mathrm{~mm})$.

Males and females of $H$. mabouia did not differ in SVL $(U=38 ; \mathrm{P}>0.05)$, body masses $(\mathrm{U}=36.5 ; \mathrm{P}>0.05)$, or mean intensity of infection $(\mathrm{U}=49 ; \mathrm{P}>0.05)$. Likewise, no significant differences were observed between SVL of P. pollicaris adult males and females $(\mathrm{U}=493.5 ; \mathrm{P}>0.05)$, or mean intensity of infection $\left(\mathrm{U}=513.5 ; \mathrm{Z}_{\text {ajusted }}=1.54\right.$; $\mathrm{P}>0.05)$. However, males have higher body mass $(\mathrm{U}=471.5$; $\mathrm{P} \leq 0.04$ ). On the other hand, both SVL and body mass of adult specimens of $H$. mabouia and $P$. pollicaris differed significantly $(\mathrm{U}=260.5 ; \mathrm{P}<0.001 / \mathrm{U}=229.5 ; \mathrm{P}<0.001$, respectively).

Six parasite species were found infecting H. mabouia: the cestode Oochoristica sp., the nematodes Parapharyngodon sceleratus Travassos, 1923, Physaloptera retusa Rudolphi, 1819, Physalopteroides venancioi Lent, Freitas, \& Proença, 1946, and Spauligodon oxkutzcabiensis (Chitwood, 1938) and the pentastomid Raillietiella mottae Almeida, Freitas and Lopes, 2008, (Table 1). Of the 76 individuals examined of H. mabouia, 26 were infected with at least one parasite species (overall prevalence $34.2 \%$ ). The prevalence of adult 
host males was $63.4 \%$, and adult females was $58.6 \%$; only two juvenile lizards were infected (prevalence of 5.6\%). The overall intensity of infection was $6.76 \pm 14.07$.

Four parasite species were found associated with P. pollicaris: Oochoristica sp., Parapharyngodon sceleratus, Physaloptera retusa, and Spauligodon oxkutzcabiensis (Table 1). Of the 118 specimens of $P$. pollicaris collected, 58 were infected with one or more parasite (overall prevalence of $49.15 \%$ ). The prevalence of adult host males was $65.9 \%$, and that of adult females was $70.3 \%$; the prevalence of juveniles was $30 \%$. The overall intensity of infection was $19.25 \pm 23.52$

There were no significant differences in the prevalence between $H$. mabouia and $P$. pollicaris $(\mathrm{Z}=0.63 ; \mathrm{P}=$ 0.4 ) and Sorensen index comparing the endoparasite faunas of the two hosts was 0.75 (75\%). However, there significant difference in the mean intensity of infection $\left(\mathrm{U}=497 ; \mathrm{Z}_{\text {ajusted }}=3.82 ; \mathrm{P}<0.001\right)$ between the two lizard species studied.

\section{Discussion}

By invading and colonizing new environments, individuals of $H$. mabouia will encounter new food resources that are intermediate hosts for parasites that differ from those of their African origin. Thus, H. mabouia appeared to be able to rid itself of its original gastrointestinal parasites (escape-from-the-enemy hypothesis, Wolfe 2002) - but the species is then colonized by the autochthonous parasite fauna (the guest-playing-host hypothesis, Criscione and Font, 2001). Hemidactylus mabouia has, however, apparently kept some of its natural parasites (from Africa), such as the acari Geckobia hemidactyli Lawrence, 1936 and the pentastomida Raillietiella frenata (Ali, Riley and Self, 1981) during its colonization of the Caribbean region and South America (Riley et al., 1991; Anjos et al., 2007, 2008).
Barton (1997) studied the endoparasites associated with a population of the toad Rhinella marina (Linnaeus, 1758) introduced into Australia and discovered that the helminth fauna of this frog had been acquired in its totality from the native fauna. The non-occurrence of exotic parasites in $H$. mabouia demonstrates that it has acquired endoparasites different from those present in its locality of origin - although Anjos et al. $(2007,2008)$ reported the African pentastomida $R$. frenata parasitizing $H$. mabouia in human habitations in Barbalha municipality (about 14 $\mathrm{km}$ from the present study site), Ceará state. It has been experimentally demonstrated that cockroaches can serve as intermediate hosts for $R$. frenata (Ali and Riley, 1983; Jeffery et al., 1985), although cockroaches were not found among the food items taken by the lizards analyzed here (unpublished data).

The pentastomide $R$. mottae was originally described as infecting Tropidurus hispidus (Spix, 1825), being reported in five other lizard species (H. mabouia, Micrablepharus maximiliani (Reinhardt and Lutken, 1861), Phyllopezus periosus Rodrigues, 1986, P. pollicaris and Tropidurus semitaeniatus (Spix, 1825), demonstrating that it is a generalist in terms of its hosts (Anjos et al., 2008; Almeida et al., 2008, 2009; Sousa et al., 2010).

The genus Oochoristica Lühe 1898 comprises 45 species parasitizing reptiles and mammals, and eight species have been reported parasitizing 13 lizard genera in Brazil (Ávila and Silva, 2010). In the present study, Oochoristica sp. is reported in the two lizard species examined - representing the first record of the genus infecting $P$. pollicaris. Oochoristica vanzolini Rego \& Rodrigues, 1965 has previously been recorded infecting H. mabouia in other regions of Brazil (Ávila and Silva, 2010). Little is known about the biology of this parasite

Table 1. Epidemiological data for Hemidactylus mabouia and Phyllopezus pollicaris from an urban area in Crato, Ceará state, Northeastern, Brazil. For each parasite the prevalence (P, in \%), intensity of infection (mean \pm standard deviation), range and the sites of infection (SI) are given. S, stomach; SI,small intestine; LI, large intestine; LU, lung.

\begin{tabular}{|c|c|c|c|c|c|c|c|c|c|}
\hline & \multirow[b]{2}{*}{ Parasite } & \multicolumn{4}{|c|}{ H. mabouia $(\mathrm{n}=76)$} & \multicolumn{4}{|c|}{ P. pollicaris $(\mathrm{n}=118)$} \\
\hline & & $\begin{array}{c}\mathbf{P} \\
(\%) \\
\end{array}$ & Int. infection & Range & Site & $\begin{array}{c}\mathbf{P} \\
(\%) \\
\end{array}$ & Int. infection & Range & Site \\
\hline \multicolumn{10}{|l|}{ Cestoda } \\
\hline & Oochoristica sp. & 1.31 & 1 & 1 & SI & 2.54 & $8 \pm 2$ & $6-10$ & SI \\
\hline \multicolumn{10}{|l|}{ Nematoda } \\
\hline & $\begin{array}{l}\text { Parapharyngodon } \\
\text { sceleratus }\end{array}$ & 22.3 & $1.87 \pm 1.2$ & $1-4$ & LI & 10.2 & $2.86 \pm 1.84$ & $1-7$ & LI \\
\hline & Physaloptera retusa & 3.94 & $23.66 \pm 34.12$ & $2-67$ & $\mathrm{~S}, \mathrm{SI}$ & 2.54 & 4.33 & $1-10$ & $\mathrm{~S}$ \\
\hline & $\begin{array}{l}\text { Physalopteroides } \\
\text { venancioi }\end{array}$ & 1.31 & 1 & 1 & $\mathrm{~S}$ & - & - & - & - \\
\hline & $\begin{array}{l}\text { Spauligodon } \\
\text { oxkutzcabiensis }\end{array}$ & 5.26 & $14.5 \pm 11.9$ & $1-28$ & LI & 50 & $23.77 \pm 24.95$ & $1-128$ & LI \\
\hline \multicolumn{10}{|l|}{ Pentastomida } \\
\hline & Raillietiella mottae & 2.63 & 4 & 4 & LU & - & - & - & - \\
\hline
\end{tabular}


as most studies involving the genus Oochoristica have been limited to descriptions of new species and reports of new hosts.

Physaloptera retusa was originally described as infecting Tupinambis teguixin (Linnaeus, 1758), but has subsequently been found in 36 other species of South American lizards (see the review by Ávila and Silva (2010)). H. mabouia and P. pollicaris represent two new host records of $P$. retusa.

Spauligodon oxkutzcabiensis was first described for the phyllodactylid Thecadactylus solimoensis Bergmann \& Russell, 2007, and infections by this parasite were later reported in nine other South American lizards: Bogertia lutzae (Loveridge, 1941); Gymnodactylus geckoides (Spix, 1825); Microlophus occipitalis (Peters, 1871); Tropidurus guarani; Phyllodactylus reissi (Peters, 1862); Phyllodactylus inaequalis (Cope, 1876); Phyllodactylus johnwrighti (Dixon \& Huey, 1970); Phyllodactylus microphyllus (Cope, 1876); and P. pollicaris (Ávila et al., 2012; Ávila and Silva, 2010). H. mabouia represents a new host of $S$. oxkutzcabiensis.

Host biological features, such diet, foraging strategies, physiology, and contact with monoxenous parasites influence the composition, richness, and structure of their helminth communities (Aho, 1990). The cestode, pentastomid, and the two nematodes of the family Physalopteridae found here are heteroxenous and use invertebrates as intermediate hosts (Anderson, 2000). The nematodes $P$. sceleratus and $S$. oxkutzcabiensis are monoxenous, and are generally acquired by the ingestion of eggs or through transcutaneous infections by their larval stages (Anderson, 2000). According to Aho (1990), infections are more commonly caused by parasites that complete their lifecycles directly within a single individual. In the present work, a greater diversity of heteroxenous parasites were encountered than monoxenous species (4 versus 2 species), although monoxenous parasites were more abundant (1536 versus 121 parasites).

According to the Sorensen similarity index, $75 \%$ of the parasites encountered were associated with both H. mabouia and P. pollicaris. At Valinhos municipality, southeastern Brazil, H. mabouia shared most of its helminth fauna with two other sympatric lizards, Mabuya frenata (Cope, 1862) and Tropidurus itambere Rodrigues, 1987 (Anjos et al. 2005). The authors also noted that H. mabouia had colonized the Neotropical region a long time ago and it was not surprising that their parasite communities were exclusively composed of local species, and very similar to those carried by sympatric lizard neighbors.

Largest (and presumably oldest) lizards tend to present higher prevalence and intensity of infection, which probably reflects their greater time of exposure to these parasites (Aho, 1990; Ribas et al., 1995). Adult H. mabouia and $P$. pollicaris differed significantly in size and weight, with $P$. pollicaris being significantly larger. Individuals of $P$. pollicaris had higher abundance of endoparasites (1487 parasites) than H. mabouia (170 parasites). Poulin (1997) noted that larger host species provide parasites with more space and greater niche diversities, and larger hosts also have greater chances of being exposed to parasites as they consume greater numbers of prey. However, of the four parasite species identified in P. pollicaris, two had monoxenous lifecycles and represented $97.4 \%$ of the total parasite abundance in these lizards.

The present study increases our knowledge of the parasite fauna and their lizard hosts in Ceará State and northeastern Brazil. Hemidactylus mabouia presented parasite entirely acquired from the native fauna. Hemidactylus mabouia showed greater diversity than P. pollicaris. However, $P$. pollicaris had higher intensity of infection than H. mabouia, showing a significant difference in the intensity of infection between the two lizards species studied. However, further studies are necessary to better understand their parasite-host interactions and the lack of relationships between the patterns of infection intensity, sex, and host size.

\section{Acknowledgements}

We are grateful to Conselho Nacional de Desenvolvimento Científico e Tecnológico - CNPq (PQ-311713/2012-2) for the research grant awarded to W. O. Almeida; the Coordenação de Aperfeiçoamento de Pessoal de Nível Superior - CAPES for the scholarship awarded to S. V. Brito. The specimens were collected under licence of ICMBio 29613-1; to Dr. Roy Richard Funch (UEFS) for suggestions and revision of English version of the manuscript; to M. E. Cabral, D. Q. Dias, D. L. Sales and O. P. Oliveira for their help with our field work.

\section{References}

AHO, JM., 1990. Helminthes communities of amphibians and reptiles: comparative approaches to understanding patterns and process. In ESCH, GW., BUSH, AO. and AHO, JM. (Eds.). Parasite communities: patterns and process. London/New York: Chapman and Hall. p. 157-195. http://dx.doi.org/10.1007/97894-009-0837-6_7.

ALI, J. and RILEY, J., 1983. Experimental life-cycles studies of Raillietiella gehyrae Bovien, 1927 and Raillietiella frenatus Ali, Riley and Self, 1981: Pentastomida parasites of geckos utilizing insects as intermediate hosts. Parasitology, vol. 86, no. 1, p. 147160. http://dx.doi.org/10.1017/S0031182000057255.

ALMEIDA, WO., SANTANA, GG., VIERIA, WLS., WANDERLEY, I., FREIRE, EMX. and VASCONCELLOS, A., 2008. Pentastomida, Raillietiella mottae, infecting lizards in an area of Caatinga, Northeast, Brazil. Brazilian Journal of Biology $=$ Revista Brasileira de Biologia, vol. 68, no. 2, p. 427-431.

ALMEIDA, WO., SANTANA, GG., VIERIA, WLS., WANDERLEY, I. and RIBEIRO, SC., 2009. Rates of pulmonary infection by pentastomids in lizards species from a restinga habitat in northeastern Brazil. Brazilian Journal of Biology $=$ Revista Brasileira de Biologia, vol. 69, no. 1, p. 427-431.

ANDERSON, RC., 2000. Nematode parasites of vertebrates: their development and transmission. 2 nd ed. Wallingford: $\mathrm{CAB}$ International. 650 p. http://dx.doi.org/10.1079/9780851994215.0000. 
ANJOS, LA. and ROCHA, CFD., 2008. The Hemidactylus mabouia Moreau de Jonnes, 1818 (Gekkonidae) lizard: an invasive alien species broadly distributed in Brazil. Natureza \& Conservação, vol. 6, no. 1, p. 196-207.

ANJOS, LA., ALMEIDA, WO., VASCONCELLOS, A., FREIRE, EMX. and ROCHA, CFD., 2007. The alien and native pentastomids fauna of an exotic lizard population from Brazilian Northeast. Parasitology Research, vol. 101, no. 3, p. 627-628. http://dx.doi. org/10.1007/s00436-007-0526-7. PMid:17384963

ANJOS, LA., ALMEIDA, WO., VASCONCELLOS, A., FREIRE, EMX. and ROCHA, CFD., 2008. Pentastomids infecting an invader lizard, Hemidactylus mabouia (Gekkonidae) in northeastern Brazil. Brazilian Journal of Biology $=$ Revista Brasileira de Biologia, vol. 68 , no. 3, p. 611-615.

ANJOS, LA., ROCHA, CF., VRCIBRADIC, D. and VICENTE, JJ., 2005. Helminths of the exotic lizard Hemidactylus mabouia from a rock outcrop area in southeastern Brazil. Journal of Helminthology, vol. 79, no. 4, p. 307-313. http://dx.doi.org/10.1079/ JOH2005288. PMid:16336713

ARAUJO, AFB., 1991. Structure of a white sand-dune lizard community of coastal Brazil. Brazilian Journal of Biology = Revista Brasileira de Biologia, vol. 51, no. 4, p. 857-865.

ÁVILA, RW. and SILVA, RJ., 2010. Checklist of helminths from lizards and Amphisbaenians of South America. Journal of Venomous Animals and Toxins including Tropical Diseases, vol. 16, no. 4, p. 543-572. http://dx.doi.org/10.1590/S1678-91992010000400005.

ÁVILA, RW., ANJOS, LA., RIBEIRO, SC., MORAIS, DH., SILVA, RJ. and ALMEIDA, WO., 2012. Nematodes of lizards (Reptilia: Squamata) from Caatinga biome, northeastern Brazil. Comparative Parasitology, vol. 79, no. 1, p. 56-63. http://dx.doi. org/10.1654/4518.1.

BARTON, DP., 1997. Introduced animals and their parasites: the cane toad, Bufo marinus, in Australia. Australian Journal of Ecology, vol. 22, no. 3, p. 316-324. http://dx.doi.org/10.1111/j.1442-9993.1997. tb00677.x.

BURSEY, CR., MCALLISTER, CT. and FREED, PS., 1997. Oochoristica jonnesi sp.n. (Cyclophyllidea: Linstowiidae) from the house gecko, Hemidactylus mabouia (Sauria: Gekkonidae), from Cameroon. Journal of the Helminthological Society of Washington, vol. 64, no. 1, p. 55-58.

BUSH, AO., LAFFERTY, KD., LOTZ, JM. and SHOSTAK, AW., 1997. Parasitology meets ecology on its own terms: Margolis et al. revisited. The Journal of Parasitology, vol. 83, no. 4, p. 575-583. http://dx.doi.org/10.2307/3284227. PMid:9267395

CRISCIONE, CD. and FONT, WF., 2001. The guest playing host: colonization of the introduced Mediterranean gecko, Hemidactylus turcicus, by helminth parasites in southeastern Louisiana. The Journal of Parasitology, vol. 87, no. 6, p. 1273-1278. http:// dx.doi.org/10.1645/0022-3395(2001)087[1273:TGPHCO]2.0. CO;2. PMid: 11780810

HOWARD, KG., PARMERLEE, JS. and POWELL, R., 2001. Natural history of the edificarian geckos Hemidactylus mabouia, Thecadactylus rapicauda, and Sphaerodactylus sputator on Anguilla. Caribbean Journal of Science, no. 3-4, p. 285-288.

Instituto de Planejamento do Estado do Ceará - IPECE, 2011. Anuário Estatístico do Ceará: perfil básico dos municipios. Available from: <www.ipece.ce.gov.br>. Access in: 15 Mar. 2012.

JEFFERY, J., KRISHNASAMY, M., OOTHUMAN, P., ALI, JH., BAKAR, EA. and SINGH, I., 1985. Preliminary observations on the cockroach intermediate host of a house gecko raillietiellid in peninsular Malaysia. Malaysian Journal of Medical Sciences, vol. 2, no. 2, p. 82-84.

KLUGE, AG., 1969. The evolution and geographical origin of the New World Hemidactylus mabouia-brokii complex (Gekkonidae, Sauria). Michigan: University of Michigan. 78 p. Miscellaneous Publications Museum of Zoology, no. 138.

LAWSON, R., FRANK, PG. and MARTIN, DL., 1991. A gecko new to the United States herpetofauna, with notes on geckoes of the Florida Keys. Herpetological Review, vol. 22, no. 1, p. 11-12.

MORAVEC, F., BARUS, V. and RYSAVY, B., 1987. On parasitic nematodes of the families Heterakidae and Pharyngodonidae from reptiles in Egypt. Folia Parasitologica, vol. 34, no. 3, p. 269-280.

POULIN, R., 1997. Species richness of parasite assemblages: evolution and patterns. Annual Review of Ecology and Systematics, vol. 28 , no. 1 , p. 341-358. http://dx.doi.org/10.1146/annurev. ecolsys.28.1.341.

RECORDER, RS., TEIXEIRA, M., CAMACHO, AG. and RODRIGUES, MT., 2012. Natural history of the tropical gecko Phyllopezus pollicaris (Squamata, Phyllodactylidae) from a sandstone outcrop in Central Brazil. Herpetology Notes, vol. 5 , p. 49-58.

RIBAS, SC., ROCHA, CFD., TEIXEIRA-FILHO, PF. and VICENTE, JJ., 1995. Helminths (Nematoda) of the lizard Cnemidophorus ocellifer (Sauria: Teiidae): assessing the effect of rainfall, body size and sex in the nematode infection rates. Ciência e Cultura, vol. 47 , no. $1-2$, p. $88-91$.

RILEY, J., POWELL, R. and SMITH, DD., 1991. Further observations of blunt-hooked pentastomids belonging to the genus Raillietiella Sambon, 1910 infecting Hemidactylus brookii (Sauria: Gekkonidae) in Africa and the Caribbean; comparison with closely related Raillietiella spp from an African skink (Mabuya perrotetii). Systematic Parasitology, vol. 20, no. 1, p. 47-57. http://dx.doi.org/10.1007/BF00009710.

ROCHA, CFD. and ANJOS, LA., 2007. Feeding ecology of a nocturnal invasive alien lizard species, Hemidactylus mabouia Moreau de Jonnès, 1818 (Gekkonidae), living in an outcrop rocky area in southeastern Brazil. Brazilian Journal of Biology $=$ Revista Brasileira de Biologia, vol. 67, no. 3, p. 485-491.

ROCHA, CFD., VRCIBRADIC, D. and ARAUJO, AFB., 2000. Ecofisiologia de répteis de restingas Brasileiras. In ESTEVES, FA. and LACERDA, LD. (Eds.). Ecologia de restingas e lagoas costeiras. Macaé: NUPEM/UFRJ. p. 117-149.

ROCHA, CFD., DUTRA, GF., VRCIBRADIC, D. and MENEZES, VA., 2002. The terrestrial reptile fauna of the Abrolhos Archipelago: species list and ecological aspects. Brazilian Journal of Biology = Revista Brasileira de Biologia, vol. 62, no. 2, p. 285-291.

ROCHA, CFD., ANJOS, LA. and BERGALLO, H., 2011. Conquering Brazil: the invasion by the exotic gekkonid lizard Hemidactylus mabouia (Squamata) in Brazilian natural environments. Zoologia, vol. 28, no. 6, p. 747-754. http://dx.doi.org/10.1590/ S1984-46702011000600007.

RODRIGUES, HO., 1970. Estudo da fauna helmintologica de Hemidactylus mabouia (M. de J.) no estado da Guanabara. Atas Sociedade de Biologia do Rio de Janeiro, vol. 12, p. 15-23.

RODRIGUES, HO., 1986. Contribuição ao estudo da fauna helmintologica de vertebrados de Nova Iguacu, RJ. Atas Sociedade de Biologia do Rio de Janeiro, vol. 26, p. 27-28. 
RODRIGUES, HO., 1994. Plagiorchis vicentei, sp. (Trematoda, Plagiorchiidae) A new trematode from Hemidactylus mabouia (Moreau de Jonnes) (Lacertilia, Gekkonidae). Zoologia, vol. 11, no. 4, p. 669-672. http://dx.doi.org/10.1590/S0101-81751994000400011.

RODRIGUES, HO., RODRIGUES, SS. and FARIA, Z., 1990. Contribution to the knowledge of the helminthological fauna of vertebrates of Marica, Rio de Janeiro State, Brazil. Memorias do Instituto Oswaldo Cruz, vol. 85, no. 1, p. 115-116. http://dx.doi. org/10.1590/S0074-02761990000100020.

SIMONSEN, PE. and SARDA, RK., 1985. Helminth and arthropod parasites of Hemidactylus mabouia from Tanzania. Journal of Herpetology, vol. 19, no. 3, p. 428-430. http://dx.doi. org/10.2307/1564276.

SOUSA, JGG., RIBEIRO, SC., ROBERTO, IJ., TELES, DA. and ALMEIDA, WO., 2010. Ocorrência de pentastomídeos
(Metameria: Ecdysozoa) no lagarto Phyllopezus pollicaris (Spix, 1825). Cadernos de Cultura e Ciência, vol. 2, no. 2, p. 64-71.

VANZOLINI, PE., 1978. On South American Hemidactylus (Sauria, Gekkonidae). Papéis Avulsos de Zoologia, vol. 31, no. 20, p. 307-343.

VANZOLINI, PE., RAMOS-COSTA, AMM. and VITT, LJ., 1980. Répteis das caatingas. Rio de Janeiro: Academia Brasileira de Ciências. 161 p.

VITT, LJ., 1995. The ecology of tropical lizards in the Caatinga of Northeast Brazil. Occasional papers of the Oklahoma Museum of Natural History, vol. 1, p. 1-29.

WOLFE, LM., 2002. Why alien invaders succeed: support for the escape-from-enemy hypothesis. American Naturalist, vol. 160, no. 6, p. 705-711. http://dx.doi.org/10.1086/343872. PMid:18707459 